\title{
Outdoor Education as Aesthetic Pedagogical Design in Nature Space Understood as Thirdspace
}

\author{
Tone Pernille Østern*, Egil Galaaen Gjølme
}

Program for Teacher Education, Norwegian University of Science and Technology, Norway

Copyright $@ 2015$ Horizon Research Publishing All rights reserved.

\begin{abstract}
Outdoor education is a way of working where the teaching is moved out of the ordinary classroom. There are different ways of organizing and defining outdoor education, but a common feature is that it gives the pupils and teachers an opportunity to engage bodily in learning processes with all of their senses, navigate in teamwork and be in concrete contact and dialogue with the environment. Different ways of learning are put into action in the meeting with a multimodal and 'alive' environment. In this article, we look at outdoor education from an aesthetic pedagogical design perspective with a philosophical approach informed by the spatial ontology found in postmodern geography, art and philosophy. Our investigation is both theoretical and practice-based. We analyse empirical material collected from a 3-day long outdoor education project (in 2013) at a teacher education institution in Norway, and look at the student teachers' $(n=199)$ experiences and evaluations through the theoretical lenses of aesthetic pedagogical design. As a result, we articulate and discuss how outdoor education can be understood as aesthetic pedagogical design in "nature space" understood as "thirdspace".
\end{abstract}

Keywords Outdoor Education, Aesthetic Pedagogical Design, Nature Space, Thirdspace, Teacher Education

This article envelops through a structure where we first present the context in focus, ending up with the research question that the article pivots around. We then describe outdoor education generally, and more specifically as part of the teacher training at our institution. We continue with a description of the analytical tool we use combined with a philosophical approach informed by the spatial ontology we find behind the concepts nature space and thirdspace. Thereafter we describe aesthetic pedagogical design as a theoretical framework that directs our gaze, at the same time as we analyse the empirical material through the lenses of this framework. Finally, we discuss how outdoor education can be understood as aesthetic pedagogical design in nature space understood as thirdspace. In this we point to the epistemological power in outdoor education.

\section{Introduction}

At the Program for Teacher Education at the Norwegian University of Science and Technology in Trondheim, Norway, we have a long tradition of including outdoor education in the teacher training. All student teachers, regardless of what subject they train to teach 1 , take part in a 3-day long outdoor education project with invited pupils (10-12 yrs old, around 100 in number) from a nearby school. Through yearly evaluations we know that the student teachers highly appreciate this outdoor education project. Quotes from the qualitative data $(\mathrm{n}=199)$ in this study reveal a very positive attitude towards the outdoor education project as part of the students' teacher training, as these examples illustrate:

- It is nice to work cross-curricularly and to be outside. (quote student teacher)

- We have been forced to think about our subjects in a different setting than usual. It has been great to combine different subjects and learn from one another. (quote student teacher)

- It is fun to combine theory with something active and practical. It makes me think more actively when I plan a subject (language) heavy with theory. (quote student teacher)

Also the quantitative data supports the impression that the teacher student appreciation of the outdoor education project is high, as table 1 with descriptive statistics shows (although there is also criticism towards parts of the project2). The questionnaire had statements that the teacher students rated on a rating scale ranging from $1=$ very good to $4=$ not good enough. That means that an average rate between 1 and 2 indicates that a majority of the students have chosen "very good" or "good" in ranging how well this statement fits their experience, while an average lower than 2 indicates less agreement with these statements.

Our impression is that outdoor education is appreciated

1 The teacher students study to teach a large variety of different school relevant subjects within science, arts, sports, languages, maths, social sciences and computer sciences.

2 The criticism is directed towards aspects of the project that are important to work with, but which are not the focus in this study. 
because it in many ways is an aesthetic experience: embodied, practical, creative, highly relational, dialogical and student-active. It also engages the student teachers differently in spatial aspects of teaching and learning than in indoor classroom teaching. In dialogue with Selander and Kress' [1] multimodal pedagogical design theory and Østern and Strømme's [2,3] aesthetic pedagogical design concept, we ask ourselves how outdoor education can be understood as aesthetic pedagogical design. Our philosophical approach is that of a spatial ontology found in the work of postmodern geographers as Soja [4,5] and Massey [6], philosopher Henri Lefebvre [7] and art philosophers and/or artists as Kramer [8] and Munjee [9]. More specifically we approach outdoor education as taking place in nature space [8] as a thirdspace $[5,9]$. The concept nature space decentralises the human into one that co-exists with nature rather than controls it, whereas thirdspace offers a framework of addressing the complexity of contemporary social spatiality through the trialectics of perceived, conceived and lived space. The article pivots around the research question: How can outdoor education be understood as aesthetic pedagogical design through the philosophical approach of "nature space" understood as "thirdspace"?

Table 1. Descriptive statistics of the student teachers' rating of statements about the three days long outdoor education project.

\begin{tabular}{|c|c|c|c|c|c|c|}
\hline & N & Minimum & Maximum & Average & Standard deviation \\
\hline 1 & $\begin{array}{c}\text { See how outdoor education can be way of creating } \\
\text { variation in teaching and learning processes }\end{array}$ & 199 & 1 & 4 & 1.41 & .628 \\
\hline 2 & Develop skills carry out outdoor education & 199 & 1 & 3 & 1.55 & .591 \\
\hline 3 & $\begin{array}{c}\text { Create a learning environment which enhances } \\
\text { collaboration and problem-solving }\end{array}$ & 197 & 1 & 4 & 1.64 & .674 \\
\hline 4 & $\begin{array}{c}\text { Develop skills to plan outdoor education for a } \\
\text { class or school }\end{array}$ & 198 & 1 & 3 & 1.69 & .632 \\
\hline 5 & Use and engage in different learning spaces & 197 & 1 & 4 & 1.76 & .671 \\
\hline 6 & $\begin{array}{c}\text { Reflect around how alternative learning spaces } \\
\text { can enhance learning and motivation for learning }\end{array}$ & 198 & 1 & 4 & 1.87 & .786 \\
\hline 7 & $\begin{array}{c}\text { Design different outdoor education classes and } \\
\text { state the reason for them }\end{array}$ & 198 & 1 & 4 & 2.12 & .737 \\
\hline 8 & $\begin{array}{c}\text { Find alternative learning spaces in order to adjust } \\
\text { outdoor education teaching to pupils with special } \\
\text { needs }\end{array}$ & 197 & 1 & 4 & 2.43 & .893 \\
\hline 9 & $\begin{array}{c}\text { Use observation of outdoor education as a tool for } \\
\text { reflection and development }\end{array}$ & 199 & 1 & 4 & 2.67 & .823 \\
\hline
\end{tabular}

1=very good, 4=not good enough. The number of teacher students that have rated the different statements vary between 197 and 199 .

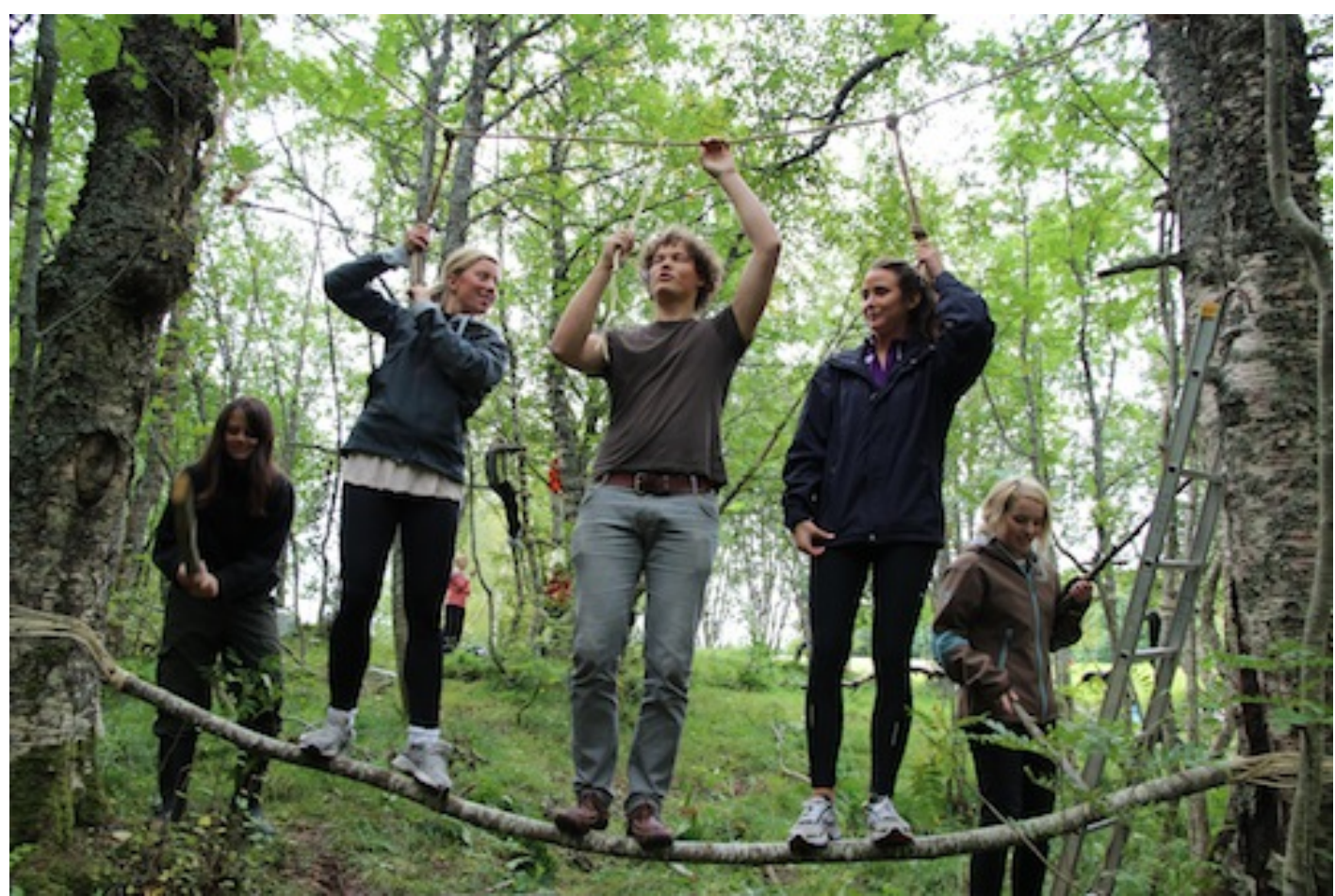

Photo 1. Student teachers in outdoor education training. (Photo: Nora Sitter) 


\section{Outdoor Education}

There is quite a lot of research literature about outdoor education. Research from Norway, for example Jordet [10] and Fiskum \& Suul [11] and other countries shows a field with a long and well-established tradition in among other the USA (for example Alexander, North \& Hendren [12]), Canada (for example Bixler, Carisle, Hammitt \& Floyd [13]), New Zealand (for example Davidson [14]), Australia (for example Ballantyne \& Packer [15]) and Spain (for example Aleixandre \& Roderiguez [16]). Here, we only give a short and comprehensive definition of what outdoor education is, mainly based in Jordet [10] and Fiskum \& Huseby [17].

Outdoor education is a way of working where the teaching is moved out of the ordinary classroom. It is a way to work where pupils and teachers engage in the local community as a resource in education - to supplement, extend and complement classroom teaching [10]. Outdoor education is a wide umbrella concept for diverse teaching and learning forms like outdoor play in the early years, school grounds projects, environmental education, recreational and adventure activities, personal and social development programs, live art education, site specific art projects, expeditions, team building, leadership training, management development and education for sustainability. There are some major points that a definition and description of outdoor education pivots around:

- Outdoor education happens in natural, urban and/or social environments where participants will have to negotiate bodily with the site and there is a heightened involvement of different senses.

- Outdoor education takes place at sites where actions have real results and consequences. Jordet [10] in this context writes about to learn about reality in reality, as the pupils engage all their senses and make personal and concrete experiences in the meeting with the environment.

- Outdoor education is experiential and it can provide a dramatic contrast to the indoor classroom. Changing climate conditions and actual interference with living matter calls for spontaneous innovation and 'real' solutions to 'real' interference.

- Outdoor education is pupil-active, pupil-centered, relational and dialogical. Participants, both pupils and teachers, learn through what they do, encounter and discover. Active learning takes form through, as well as develops, inquiry, experience, problem-solving, experiment, expression, feedback, reflection, review and cooperative learning. Kolb [18] defines learning in this context as a continuously investigating process.

- Outdoor education is interdisciplinary, the relationships involving people and natural resources are central and it draws in energy and inspiration from all around [19].

\section{Outdoor Education in Teacher Education}

A 3-day long outdoor education project is carried out across all subject studies in the teacher training at our institution. To carry out the project is a huge undertaking as it involves around 300 student teachers, 100 visiting school pupils and their teachers, and around 20 teacher educators as lecturers and supervisors. Good planning and preparation is needed in relation to the outdoor sites used, safety, relevant equipment and materials, as well as teaching and supervision of the student teachers. The aim with the priority of outdoor education as part of the teacher training is to give the teacher students experience and skills with, insight in and motivation for alternative learning spaces and pupil-active learning processes. The outdoor education project with the student teachers is fulfilled through the phases of planning, carrying out and reflection.

\section{Planning}

The preparation and planning phase lasts for two days. The three day long project starts with a lecture for everybody about what outdoor education is. What then follows is a division into cross-curricular teams that are going to plan one outdoor station each. When the school pupils arrive on the third day, they circle the different stations making up one large learning design together. One important aspect of the planning phase is that the teams have to discuss the possibilities and implications for the different subjects to be treated at their station. One team might consist of student teachers studying for example science, arts and maths. The task is to plan for a station where learning process can happen in connection to all these subjects.

\section{Carrying out}

On the day of carrying out the planned outdoor education sessions, the school kids arrive with their teachers to the outdoor site selected. The teacher students are responsible for all aspects of the day together with the school pupils; welcoming them, creating good and trustful relationships, carrying out the teaching sessions as well as aspects like having lunch together (which is also included in the learning goals; to prepare food in the outdoors). The teachers from the school take part, assist and observe so they can give feedback to the teacher students later. The teacher educators remain in the background as observers and assistants if needed. The teambuilding and learning processes take part mainly between the student teachers and school pupils.

\section{Reflection}

After a joint evaluation session of the day, the school kids with their teachers leave, and the teacher students and teacher educators keep reflecting. Participants share and discuss experiences, comments and questions regarding any theme that comes up,. The students also (voluntarily) evaluate the 3-day long project through an anonymous questionnaire (which we use in this study). Also the school kids reflect about the day, back at school with their teachers; 
they write evaluations and send them to the teacher students.

\section{A Philosophical Approach Based in Postmodern Spatial Ontology}

Outdoor education should not be understood as a method or one way of working, as it embraces a great diversity of practices, and therefore appears more like an educational philosophy than a methodological concept. Dewey' [20] transactional theory of knowing, in which learning is believed to happen in transactions of living organisms and their environments through processes of doing and undergoing is often understood as underpinning outdoor education $[10,21]$. In this study we offer an additional perspective as we emphasize the possibilities of new experiences of space and belonging offered to the participants in outdoor education in viewing it from the philosophical approach of postmodern spatial ontology found behind the concepts nature space and thirdspace.

Kramer [8] has adopted the term nature space from movement teacher Bettina Mainz' German concept Naturraum. Mainz explains nature space as "always in relationship to space being 'alive and happening', which is true for any space" and further that nature space "... has a specific being, a momentary atmosphere, a density, pressure conditions, openings, movements, stillness, proportions and rhythms, in which I can move" (Mainz in personal communication with Kramer, here in Kramer [8, p.163]). Outdoor education takes place in nature space being 'alive and happening'. Kramer argues that an attitude with a slightly decentralized position of the human as the sole center of the environments - controlling it - into somebody moving alongside a multitude of change and movement already happening, has crucial impact on presence, belonging and creative practice. We see this slightly decentralised position of both teacher and pupils from controlling the learning environment into agents moving alongside a multitude of change and movement already happening as an experience rich of learning possibilities that outdoor education offers. As a mover in nature space in outdoor education, one is required to find forms and possibilities between adaptation, intervention, co-existence, resistance and play rather than trying to exercise control and dictate the environments [8, p. 17]. Kramer further writes that attention to the materiality of the human body and the material, textural and sensual stimuli present can foster a sense of belonging in the midst of nature.

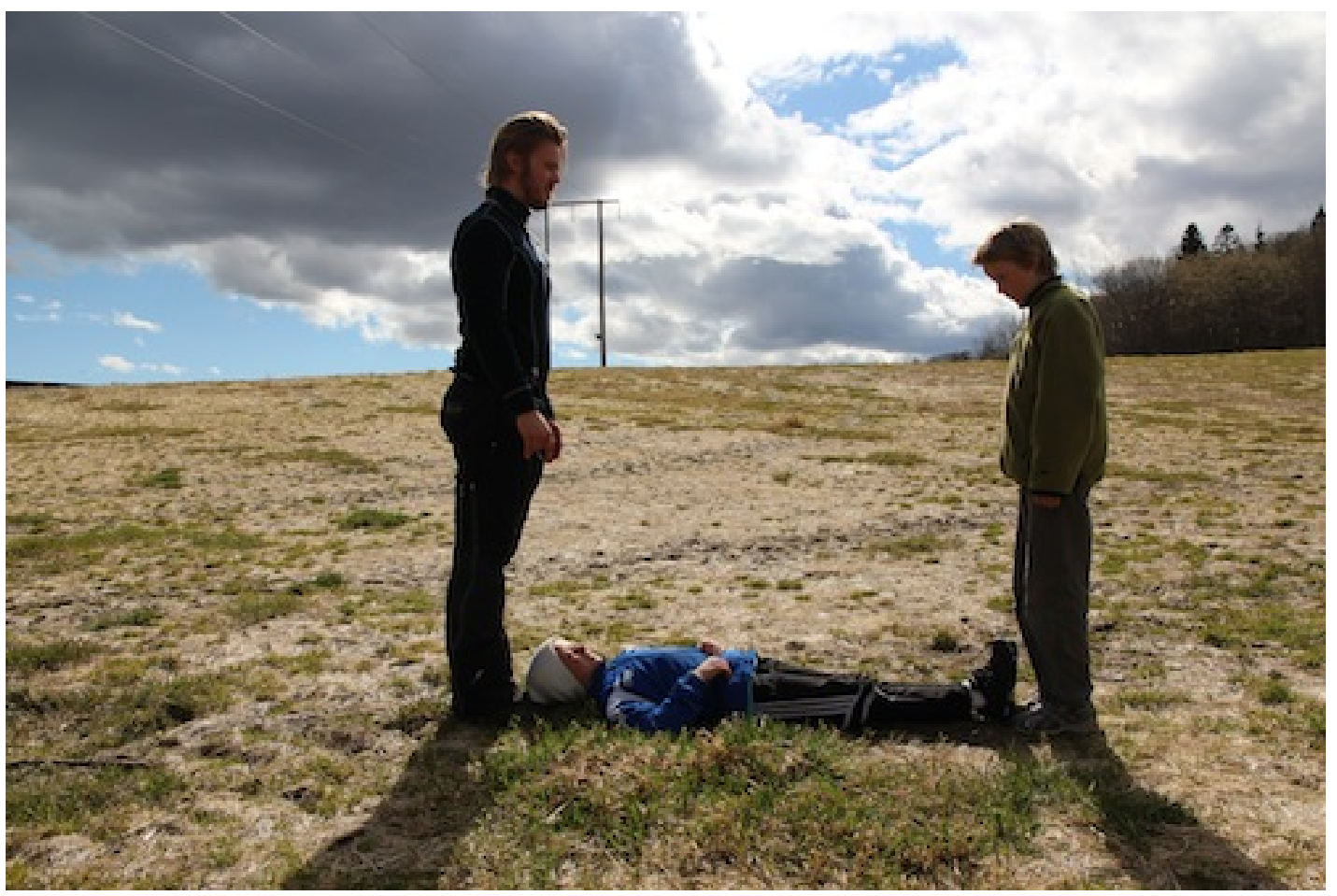

Photo 2. School kids and student teachers interacting with the grass, air, wind, soil, the materiality of their own body and the relationships between them in outdoor education. Photo: Nora Sitter. 
The critical postmodern human geographer Soja's model of thirdspace embraces the plurality of spatial understandings, and he advocates a field of a new spatial ontology that offers "the possibility of a balanced interpretation of space, time and being" [4,5]. In dialogue with the ideas of critical sociologist Lefebvre [7] he presents thirdspace as trialectical categories of space, which facilitates greater awareness of the "cacophony of spaces" [5, p.59]. This cacophony of spaces impacts site-specific events like outdoor education (see also [9, p.132]). The three spatial categories in thirdspace are perceived space, conceived space and lived space. Perceived space is measurable and quantifiable spatial information, "the absolute and relative locations of things and activities, sites and situations ... in the concrete and mappable geographies of our lifeworlds" [5, p.75]. Conceived space is about how social reality is spatialized, and as Soja states, there is no unspatialized social reality [5, p.46, original emphasis]. Urban planners, for example, aggressively dictate human behavior [9, p.133]. Thinking about how school architects with great impact dictate school pupils' (and teachers') behavior, disciplining their bodies $[22,23]$, the perspective of conceived space receives epistemological power. McDowell $[24, p .5$, here in $[9$, p.134]] notes that depending on personal history and social codes connected to class, gender and race "occupants of the same Cartesian spaces may live in very different "places"'. The embodiment, teamwork and creativity embedded in outdoor education offers a means to disturb, interrogate with and protest against the embedded social codes in conceived space. Lived space, again, refers to how the space is directly lived through kinesthetic experiences. Munjee [9, p.134] writes that lived space perspectives offer an exploration of the repetitive physical practices that humans do and which contribute to the production of space. Outdoor education offers experiences and increased awareness of these spatial layers, which encourages broad and holistic understandings of spaces and places [9, p.132].

With this spatially oriented philosophical approach as a perspective to look from, our analytical tool in handling the empirical material is the framework of aesthetic pedagogical design as defined by Østern \& Strømme [2,3] in dialogue with Selander \& Kress' [1] multimodal pedagogical design theory. Selander and Kress suggested the concept "pedagogical design" as a metaphor for how teaching and learning can be understood. With the design concept there is an emphasis on the fact that content (the 'what') clings inseparably together with the form (the 'how') of the teaching. The teacher creates pedagogical design for learning in planning and carrying out teaching, whereas the pupils create design in learning as they learn. Design has a clear spatial aspect, also in connection to the design of teaching processes. A pedagogical design is like an architecture that connects space, time and being in learning processes. Multimodality is highlighted in Selander \& Kress' multimodal pedagogical design theory 3 . Human beings

3 For more reading on pedagogical design and multimodality, we refer to [1,26-30] create, learn and communicate in different modalities (words, sounds, movements, visuals, and so on), and the forms created express our knowledge and understanding at a given point. Such forms or signs of learning can be, for example, objects, texts, drawings, movements or wooden artefacts. In the Norwegian school context, written texts are recognized and appreciated as a means of learning to a higher degree than other, multimodal products. On the other hand, the tradition for and appreciation of outdoor education is also strong in the Norwegian context. The outdoor space is one rich of modalities, not the least spatial modalities. The outdoor space in itself, with the blowing wind, high sky, smells and sounds in rural or urban settings, has modal density [25, p.255]. It is not a flat environment, but a rich, dynamic and intensive space, which easily engages sensory involvement and social interaction from pupils and teachers.

In a research and development project (2011-12) carried out in teacher education and at two secondary schools in Norway, Østern and Strømme [2,3] developed the concept "aesthetic pedagogical design" in dialogue with Selander \& Kress' theory [1]. Aesthetic pedagogical design is characterised by [2,p.24]:

- A comprehensive aesthetic approach to learning

- Emphasis on multimodality

- A view on difference among pupils as a generative force in class

- Inquiry-based and dialogical learning

- Emphasis on dramaturgical thinking in teaching

- Focus on embodied learning and teaching

- Art experiences as an important aspect of learning

In this study, we from a spatially oriented philosophical approach use these aspects of aesthetic pedagogical design as analytical categories, which we look for in the quantitative and qualitative data generated in the outdoor education project under study. As we analyse the material, we define each aspect in dialogue with Østern \& Strømme [2,3] and we also end up adding aspects to what aesthetic pedagogical design is from the perspective of outdoor education.

\section{Outdoor Education as Aesthetic Pedagogical Design}

An aesthetic approach

The word "aesthetic" has its linguistic root in the Greek word "aesthesis", which in short means to perceive and understand with the senses, or the primary process through which the world can be experienced, understood and shared 4 . In this wide definition, we understand aesthetic processes as broadly important processes where the world is experienced, made known, understood and shared between people; people who are always sensational, experiencing and relational. The experience of outdoor education as an

4 Se for example the definition of aesthesis made by the $\mathrm{PhD}$ program in artistic research at University of the Arts in Helsinki, online available from http://www.teak.fi/About_the_programme (accessed 27.09.2013) 
aesthetic experience in this broad definition is clearly visible in the empirical material, shown through quotes like:

- We have used ourselves physically and bodily. (quote student teacher)

- It was especially fun to see how the kids change as they are allowed to express themselves in physical activity at the same time as they are engaged in learning processes. (quote student teacher)

- It is great to see how engaged the pupils become in the outdoor activities. (quote student teacher)

In the quotes, a perspective of the lived space [5] can be found. The student teachers refer to both own bodily experiences that are very different from in-classroom experiences of teaching, and to the joy they sense in the school kids bodies as they are allowed to express themselves in physical activity. They also draw a line between these embodied, aesthetic experiences and learning processes (for example [20]).

\section{Multimodality}

Multimodal pedagogical design theory incorporates all modalities that are available for humans to understand the world and make meaning as part of the world. The outdoor environment quite naturally consists of a rich range of modalities, like colours, different materials, tastes, smells and continuous movement. In outdoor education both theoretical and practical knowledge forms are valued, and traditionally more theoretical subjects can be worked with in more practical ways. In this way, the distinction between 'theory' and 'practice' blurs though multimodal teaching and learning and the result is more varied teaching and learning processes. The multimodality of outdoor education and its possibilities to create variation in teaching and learning processes is highlighted in the empirical material. In the rating part of the questionnaire, the statement "See how outdoor education can be a way of creating variety in teaching and learning processes" received a high average ranking of 1.41. Also the quotes in the qualitative data reveal that the multimodality of the outdoor environment is something that influences the student teachers, and make them more creative as teachers:

- The outdoor environment is a fantastic place to teach. There are so many possibilities in the wood. (quote student teacher)

- It has been amazing! It extends our teaching tools as teachers and gives us a broader teaching horizon. (quote student teacher)

We argue that it especially the rich spatial nuances in the outdoor environment that turns the environment into a nature space like Kramer [8] defines it. This is a space where the human being can have the experience of being somebody moving alongside a multitude of change and movement already happening [8,p.163]. This experience has, according to Kramer, crucial impact on creative practice. This is the influence we see in on the student teachers' creative practice as teachers. They experience the many possibilities of the outdoor environment, and how these invite to learning processes connected to intervention, play and co-existence. In connection to multimodal theory, Wohlwend [25,p.255] writes about modal density. In dialogue with that concept and based on our reading of the student teachers' experiences in this study, we find the experience of spatial nuances and layers very powerful in the data we have. From the perspectives of outdoor education we add the aspect of spatial density as one category that characterize aesthetic pedagogical design $[2,3]$.

\section{Differences among pupils as a value}

Based on our own experience and the philosophical frame presented earlier, we suggest that outdoor education invites to inclusive teaching. Different pupils with different starting points and previous experience get the possibility to investigate and express their learning in the teamwork and multimodal environment offered by the outdoor environment. As outdoor education usually is inquiry-based, the result is not accurately pre-determined and the pupils can be truly co-creative in their learning processes. Still, our pre-understanding is not confirmed by the data generated in this study. On the opposite, the statement "Find alternative learning spaces in order to adjust outdoor education teaching to pupils with special needs" in the questionnaire receives a fairly low ranking with an average of 2.12 (see table 1). In the qualitative data, there are many quotes about building relationships and teambuilding, but none about differences among pupils. We do not have background information about the school kids that participated in the outdoor education project, and we do not know if there for example were young people with disabilities in the classes. One reason why the student teachers do not touch the aspect of differences among pupils might be that the school class attending was, or was perceived as, rather homogenous. Another explanation might be, that the aspect of inclusive pedagogy was not emphasised well enough from the teacher education institution. Still, rather than coming to the conclusion that an understanding of the difference among pupils as a generative force in outdoor education generally is absent, we conclude that this aspect was under-communicated in this specific project. From the perspective of conceived space [5] we do believe that the embodiment, teamwork and creativity embedded in outdoor education offers a means to disturb, interrogate with and protest against the spatial "places" formed by social codes that different people can "live in". In this, outdoor education receives empowering influence and has the potential of being deeply inclusive.

\section{Inquiry-based and dialogical learning}

We define inquiry-based learning as a way to learn where one is not 'given' pre-determined knowledge, but instead takes part in creating knowledge. Doing, exploring, investigating, processing, and creating, are processes in which the pupils take part in producing knowledge, thereby creating a sense of ownership to it as well. Inquiry-based 
learning is dialogical. We read both aspects of experiences of inquiry-based and dialogical teaching and learning in the data we have, but even further we find that the relational aspect is emphasised. The student teacher have deep experiences of collaboration in teams and building relationships in ways that are possible only because of the kind of nature space that the outdoor environment offers. The statement that outdoor education "creates a learning environment which enhances collaboration and problem-solving" receives a high average of 1.64 (see table 1) and many quotes in the qualitative data lift forwards this aspect:

- It was nice to see how much the pupils enjoyed it, and not the least it was a great way of building relationships. (quote student teacher)

- It is easy to get lost in books and the indoor classroom, and it is great to be reminded that the relationships between people still are the most important aspect of teaching and learning. This aspect becomes very visible in this kind of teaching. I in a way fell in love with my choice of future profession again, which is needed once in a while. (quote student teacher)

Dysthe [31] (2012) described dialogue-based teaching as investigating themes, exchanging meanings, and developing new thoughts. Further, inspired by Bakhtin [32], she wrote, that real dialogue can arise only when it is authentic and neither teacher not pupil knows the answer beforehand. It is exactly this unknown that allows the learning to be inquiry-based and problem-solving. As the perceived space [5] of the outdoor environment can never be fully controlled, and will vary according to weather, winds, temperature, other people and special circumstances, outdoor education will always have an aspect of unpredictability. The student teachers are slightly decentralised from somebody having strict control with the environment into somebody who loosely directs learning processes in a nature space made up of a multitude of change and movement already happening [8]. This opens up a space with enhanced possibilities of dialogue and inquiry-based learning. The empirical material we have from this study reveals that the aspect of building relationships is especially important in outdoor education and that it becomes visible, materialised and felt deeply in new and vitalising ways. We understand this as the perspectives of lived space blurring with conceived space [5]. The space is directly lived through kinaesthetic experiences in which the conceived space about social reality is distorted and re-constructed in a vitalising way. Relationships grow stronger trough the spatial richness offered in nature space. Social relationships can deepen, be strengthened and find new forms through the interaction with and in nature space. From the perspective of outdoor education, we would like to add to Østern \& Strømme's [2,3] definition of aesthetic pedagogical design, an inquiry-based, dialogical and relational aspect.

\section{Dramaturgical thinking in teaching}

In the empirical material we have, there are no direct questions or comments about dramaturgical thinking. We still argue that the planning and fulfilling of outdoor education is characterised by an alternative and in teaching contexts marginalised teaching dramaturgy which Gjølme \& Østern [33] call montage dramaturgy. Dramaturgy is about composing, and through dramaturgical thinking in the teaching context one focuses on the composition of the teaching. Through dramaturgical thinking, the teacher actively works on creating curiosity, getting the pupils "hooked" into the learning processes, building excitement, and creating variety in the work [34]. In dramaturgical thinking, the body is an important element to create engagement. It is engaging to "do" and to move as you learn.. In accordance with montage dramaturgical thinking [33], the teaching instead of being linear and oriented towards specific and pre-planned goals, is composed as consisting of different, co-existing layers. Each layer allows for meaning-making and dialogue. Gjølme \& Østern [33,p.103] defined three layers in outdoor education: a) a knowledge-building layer, which is the concrete and thematic layer, b) an experiential layer, which consists of the different modalities (in outdoor education with many spatial nuances) and sensory experiences, and c) an insight-creating layer, which is how the pupils create metaphoric meaning through their experiences.

\section{Embodied learning}

Embodied learning is highlighted in the student teachers' experiences of outdoor education. There are numerous quotes in the qualitative data that reveal that the student teachers had heightened experiences of their own and the pupils' embodied engagement in the learning activities:

- We have used physical and embodied aspects of ourselves in relation to the subjects taught and the wood in a unique and energizing way. (quote student teacher)

- I think it has been interesting, exciting and important to work practically with outdoor education. We have learnt a lot about how to work cross-curricularly in the outdoors and we have seen how much the pupils enjoy it. (quote student teacher)

Some quotes also highlight the importance for themselves to work practically (embodied) in their teacher training:

- I learn so much more from working practically than sitting still during a lecture. (quote student teacher)

It is in a way obvious that the body is important for learning, both for school kids and student teachers, since all sides of human sensory and cognitive organs are involved in learning. In a sensory-philosophical perspective the human being in the world is seen as being in continuous movement between sensing and understanding [35,p.49]. Still, embodied learning is not understood as a central aspect of the general education either in school or in teacher education. This is turned around in outdoor education. The body-subject 
[36] as the investigating, active and creative learner is put in the foreground. We argue that in outdoor education this embodied learner is allowed to appear in the meeting with nature space with its spatial layers creating spatial density. A sense of belonging in the midst of nature can arise from experiencing the materiality of the human body in interaction with the material, textual and sensual stimuli presented by the environment $[8, p .171]$. From the perspective of lived space, nature space with all its stimuli dialogues directly with the pupils' and teachers' skin (a large sensory organ) and all the other senses, allowing the participants to live the space directly through kinestethic experiences. The human body produce nature space as it interacts with it.

Fiskum \& Suul [11,p.139-41] further describe how different knowledge forms enrich outdoor education, both theoretical and practical forms of knowledge. The body is central for all forms of practical knowledge, as well as for developing cognitive and theoretical knowledge. Also some of the quotes in the qualitative data in this study show that the student teachers have experienced a close connection between theory and practice in outdoor education:

- It obviously was nice to try something different and practical, but I also have found it theoretically rewarding. It was important to develop an understanding of the value in outdoor education and other activities that confront more traditional ideas about school. (quote student teacher)

In outdoor education many different forms of knowledge are put into play and developed though embodied interaction with nature space.

\section{Art experiences as an important aspect of learning}

In outdoor education as used it in the project under study, art forms like drama, dance, handicraft in for example wooden material, music and film are frequently integrated. The school pupils may have art experiences either through their own art making, or through shorter elements of performance that the student teachers have prepared for them as part of the larger outdoor education design. Both Kramer [8] and Munjee [9] operate in live art or site-specific art contexts. Munjee [9] emphasises the artist's possibility to interact with, twist and turn the trialectical categories of space (perceived, conceived and lived space), thereby through site-specific art facilitate greater awareness of the "cacophony of spaces" [5,p.59]. Kramer again points to how nature space offers a specific being, a momentary atmosphere of stillness and movement in which movers can act. Live art education within the frames of cross-curricular outdoor education can emphasise this moulding of the spatial layers offered by the environment, and even bring attention specifically to them through different artistic expressions. Some quotes in the qualitative data material reveal that the student teachers have become more aware of the art subjects, and the connection between art subjects and other subjects:

- It has been nice to work with other students with background in a different school subject. It seems that languages and drama have a lot to learn from one another. (quote student teacher)

Dialogue with art demands an active involvement by the pupils. Outdoor art experiences are fully possible, and dare we say, often more engaging and dialogical than art experiences in more formal art or performance venues.

\section{Conclusion: The Epistemological Power in Outdoor Education}

In this article we have analysed outdoor education with the framework of aesthetic pedagogical design as analytical tool, with a philosophical approach influenced by a postmodern spatial ontology found behind the concepts nature space and thirdspace. We have analysed empirical material consisting of anonymous questionnaires filled out by 199 student teachers after a 3-day long outdoor education project as part of their teacher training. As a result, we are able to describe and understand outdoor education as aesthetic pedagogical design characterised by the following features. The aspects marked with bold, italic font are categories added to Østern \& Strømme's [2,3] definition of aesthetic pedagogical design from the perspective of outdoor education. Outdoor education as aesthetic pedagogical design is characterised by:

- A comprehensive aesthetic approach

- Emphasis on multimodality

- Emphasis on spatial density

- A view on difference among pupils as a generative force in class

- Inquiry-based, dialogical and relational learning

- Emphasis on dramaturgical thinking in teaching

- Focus on embodied learning and teaching

- Art experiences as an important aspect of learning

To analyse the empirical material from a spatially oriented perspective, with the influence of especially Soja [5], Kramer [8] and Munjee [9], has increased our awareness about the importance of the matrix of multi-layered spatiality which outdoor education envelops in, depends on and also produces through human engagement with the space. Outdoor education receives forceful epistemological power once the trialectical categories perceived, conceived and lived space [5] that outdoor education touches upon, challenges, blurs and changes is fully understood. Outdoor education becomes a critical voice, challenging indoor classroom epistemological architectures that dictate teachers' and learners' behaviour into passive bodies. Outdoor education seen from a spatially oriented philosophical perspective instead offers a different and powerful epistemology where learning and teaching takes place through the possibilities of adaptation, intervention, co-existence, relating, resistance, creative practice and play instead of exercising precise control over the environments and the learners moving in and alongside it [8].

The spatial density of nature space [8], and the emphasis 
of the human body as materiality interacting with the materials, textural and sensual stimuli presented by a space 'alive and already happening', has crucial impact on presence, belonging and creative practice in outdoor education. The sense of presence, belonging and creativity that outdoor education offers is highly relational. In outdoor education, tasks and challenges are solved together, and in the problem-solving, which involves the active, embodied learner, energizing relationships are built. There is a slight decentralisation of the individual to the fellowship, of the human as controller of the environment to somebody who moves along with, and belongs to, a multitude of change and movement already happening [8]. There is also an empowering possibility connected to the perspective of conceived space, as the aspects of embodied teamwork and relational creativity in outdoor education, offers a means to disturb and protest against the spatially influent social codes connected to differences like gender, class, race and ability.

To view outdoor education as aesthetic pedagogical design with highlighted spatial density and possibilities, opens up for a perspective on the outdoor education teacher as a designer who knows that the content (the 'what') and the form (the 'who') of the teaching cling tightly together. The teacher understood as a designer of outdoor education as aesthetic pedagogical design, connects space, time and being in learning processes. Outdoor education as aesthetic pedagogical design in nature space [8] receives epistemological power, as it is understood through the concept of thirdspace [5]. It touches, blurs and challenges perceived, conceived and lived space as it offers embodied and highly relational learning processes with crucial impact on presence, belonging and creative practice.

\section{REFERENCES}

[1] S. Selander, S., G. Kress. Design for lärande - ett multimodalt perspektiv / Design for learning - a multimodal perspective, Norstedts, Stockholm, 2010

[2] T.P. Østern, A. Strømme. Sanselig didaktisk design. SPACE ME / Aesthetic pedagogical design. SPACE ME, Fagbokforlaget, Bergen, 2014

[3] T.P. Østern, A. Strømme. Learning through Aesthetic Pedagogical Design. The Educational Forum, 2014, Vol. 78, No. $4,378-388$

[4] E.W. Soja. Postmodern geographies: The reassertion of space in critical social theory, Verso, New York, 1989

[5] E.W. Soja. Thirdspace: Journeys to Los Angeles and other real-and-imagined places, Blackwell, Malden, MA, 1996

[6] D. Massey. For space, SAGE, London, 2005

[7] H. Lefebvre. Translated by D. Nicholson-Smith. The production of space, Blackwell, Malden, MA, 1974/1991

[8] P. Kramer. Dancing in nature space - attending to materials, In S. Ravn \& L. Rouhiainen (eds.), Dance spaces. Practices of movement, University of Southern Denmark, Odense, 2012, $161-176$

[9] T. Munjee. Appreciating "Thirdspace". An alternative way of viewing and valuing site-specific dance performance, Journal of Dance Education, Vol. 14, No. 4, 130-35

[10] A.N. Jordet. Klasserommet utenfor. Tilpasset opplæring i et utdvidet læringsrom / The classroom outside. Teaching in an extended learning place, Cappelen Akademisk Forlag, Oslo, 2010

[11] T.A. Fiskum, U. Suul. Hvordan kan ulike kunnskapsformer berike undervisningen i uteskolen?/ How can different knowledge forms enrich outdoor education teaching activities?. In T.A. Fiskum \& J.A.Husby (eds.), Utskoledidaktikk. Ta fagene med ut / Outdoor education. Bring the subjects outdoors, Cappelen Damm, Oslo, 2014, $137-146$

[12] J. Alexander, M-W. North, D.K., Hendren. Master gardener classroom garden project: an evaluation of the benefits to children, Children's Environment, Vol. 12, No. 2, 1995, 256-63

[13] R.D. Bixler, C.L. Carlisle, W.E. Hammitt, M.F. Floyd. Observed fears and discomforts among urban students on field trips to wildland areas, Journal of Environmental Education, 1994, Vol. 26, No. 1, 24-33

[14] L. Davidson. Qualitative research and making meaning from adventure: a case study of boys' experiences of outdoor education at school, Journal of Adventure Education and Outdoor Learning, Vol. 1, No. 2, 11-20

[15] R. Ballantyne, J. Packer. Introducing a fifth pedagogy: experience-based strategies for facilitating learning in natural environments, Environmental Education Research, 2009, Vol. 15, No. 2, 243-62

[16] M.P.J. Alexixandre, R.L. Rodriguez. Designing a field code: environmental values in primary school, Environmental Education Research, 2001, Vol. 7, No. 1, 5-22

[17] T.A. Fiskum, J.A.Husby (eds.). Utskoledidaktikk. Ta fagene med ut / Outdoor education. Bring the subjects outdoors, Cappelen Damm, Oslo, 2014

[18] D.A. Kolb. Experimental learning: experience as the source of learning and development, Prentice Hall, Englewood Cliffs, New Jersey, 1984

[19] S. Priest. The Journal of Environmental Education, Vol. 17, No. 3, 1986

[20] J. Dewey. Experience and nature, Dover, New York, 1958

[21] E.G. Gjølme, L.V. Sandvik. Uteskole som pedagogisk verktøy / Outdoor education as a pedagogical tool. In Ingebrigtsen og Sigmundsson (eds.), Idrettspedagogikk / Sport pedagogy, Universitetsforlaget, Oslo, 2015 (in press)

[22] H.P. Ulleberg. Skolegården - et diskursivt rom / The school yard - a discursive space. In K. Steinsholt, S. Dobson (eds.) Verden satt ut av spill. Postmoderne pedagogiske perspektiver / The disengaged world. Postmodern pedagogical perspectives, Tapir Akademisk Forlag, Trondheim, 2010

[23] R. Øfsti. Undervisningas rom. Læreren som scenograf / The teaching space. The teacher as set designer, In A-L. Østern 
(ed.), Dramaturgi i didaktisk kontekst / The dramaturgy of teaching, Fagbokforlaget, Bergen, 2014, 87-120

[24] L. McDowell. Gender, identity and place: understanding feminist geographies, University of Minnesota Press, Minneapolis, 1999

[25] K.E. Wohlwend. Playing their way into literacies: Reading, writing, and belonging in the early childhood classroom, Teachers College Press, New York, 2011

[26] C. Jewitt. Didaktik som multimodal design / Teaching as multimodal design, In A.-L. Rostvall, S. Selander (Eds.), Design för lärande /Design for learning, Norstedts, Stockholm, 2008, 242-52

[27] C. Jewitt. An introduction to multimodality, In C. Jewitt (Ed.), The Routledge handbook of multimodal analysis, Routledge, London, 2009, 14-27

[28] G. Kress, T. van Leeuwen. Multimodal discourse: The modes and media of contemporary communication, Hodder Education, London, 2001

[29] G. Kress. What is a mode? In C. Jewitt (Ed.), The Routledge handbook of multimodal Analysis, Routledge, London, 2009, 54-67

[30] G. Kress. Multimodality: A social semiotic approach to contemporary communication. Routledge, New York, 2010
[31] O. Dysthe. Dialogbasert undervisning: Kunstmuseet som læringsrom / Dialogical teaching: The art museum as a learning space, Fagbokforlaget, Bergen, 2012

[32] M. Bakhtin. Det dialogiska ordet / The dialogical word, Anthropos, Gråbo, 1991

[33] E.G. Gjølme, A-L. Østern. Å forholde seg til virkeligheten i virkeligheten - uteskolens dramaturgi / To relate to reality in reality - the dramaturgy of outdoor education. In A-L. Østern (ed.), Dramaturgi i didaktisk kontekst / The dramaturgy of teaching. Fagbokforlaget, Bergen, 2014, 98-114

[34] A-L. Østern (ed.). Dramaturgi i didaktisk kontekst / The dramaturgy of teaching, Fagbokforlaget, Bergen, 2014

[35] T.A. Kjær. Mennesker taler først med kroppen-idéhistoriske og sansefi losofi ske perspektiver på forholdet mellem person og profession / Bodily communication-Historical and body philosophical perspectives on the relationship between person and profession. In H. Winther (Ed.), Kroppens sprog $\mathrm{i}$ professionel praksis-om kontakt, nærvær, lederskab og personlig kommunikation / Body language in professional practice - contact, presence, leadership and personal communication, Billesø \& Baltzer, Denmark, 2012, 40-54

[36] M. Merleau-Ponty. Translated by Colin Smith. The Phenomenology of Perception. Routledge, London and New York, 1962/2002 